\title{
Ово је трећи пут како се преселио. - Перфекат или аорист у модерном грчком језику?
}

\section{Мaja Г. Баћић*}

Универзитет у Београду, Филолошки факултет, Катедра за неохеленске студије

\section{Кључне речи:}

перфекат

аорист

модерни грчки као J2

\section{Апстракт}

Рад има за циљ да представи сличности и разлике између перфекта и аориста у модерном грчком језику, будући да позиционирање перфекта на временској линији може зависити од различитих синтаксичко-семантичких услова. Конкретније, ово време користи се како би се радња започета у прошлости повезала са садашњошћу, па се из тог разлога убраја и у презентска и у прошла времена. С друге стране аорист представља доминантно прошло време, те неретко може заменити перфекат. Из тог разлога, перфекат представља сложену тему у настави савременог грчког као страног. За потребе израде овог рада спроведено је квантитативно истраживање у коме су учествовали студенти друге године основних академских студија модерног грчког као J2 на Катедри за неохеленске студије. Добијени резултати показали су да већина испитаника, уколико реченични искази не обухватају временске одредбе које упућују на перфекат, бирају аорист као доминантније време. (примљено: 18. јануара 2021; прихваћено: 26. јуна 2021) www.anali.fil.bg.ac.rs

\section{АНАЛИ}

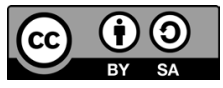

Филолошки факултет Катедра за неохеленске студије

Студентски трг 3

11000 Београд, Србија maya.bacic@hotmail.com 


\section{1. Увод}

Како би комуникација могла да се одвија несметано, односно да се порука на прави начин пошаље те разуме, неопходно је да саговорници пружају и поседују информације о прецизном времену одвијања радње. Из тог разлога, већина језика (са изузетком кинеског нпр) ${ }^{1}$ поседује категорију глаголског времена, која се у литератури традиционално дефинише као граматикализација временске локације радње, стања или збивања у односу на време приповедања, односно саопштавања (Binnick, 2012: 507; Joshi, 2014: 1; Станојчић/Поповић, 2011: 112; Xydopoulos, 1996: 33; Moser, 2003: 236-237). Тако, велики број светских језика (попут нпр. савременог грчког и енглеског) који поседује наведену категорију исту изражава морфолошким облицима глагола, адвербијалима, инхерентним темпоралним особинама глагола и принципима дискурса (Рађеновић, 2017: 23, 25; Станојчић/Поповић, 2011: 112).

Како наглашавају поједини аутори (Whorf 1956; Lakoff \& Johnson 1980; Binnick 1991), људи поимају време у просторном смислу. То би значило да конструкције које се употребљавају да означе временске односе неретко акценат стављају на продужетак или скраћивање радње, повратак у прошлост или смештање исте у будућност. Из тог разлога лингвисти време локализују на тзв. темпоралној ^инији, подељеној на сегементе означене као прошлост, садашњьост и будућност (Michaelis, 2006: 1). Ипак, треба имати у виду да не категоризују време сви језици на исти или сличан начин (Lyons, 1977: 305). Другим речима, традиционална подела глаголских времена на прошлост, садашњост, те будућност, не мора нужно бити извршена на тај начин.

Управо из тог разлога, поједини глаголски облици, у зависности од утицаја различитих морфолошких, сематичких и синтаксичких фактора, могу прелазити из једне временске категорије у другу, те поседовати обе, што доводи до тога да бивају сагледани на више начина (Мутавџић, Тодоровић и др., 2011: 83). Стога, позиционирање перфекта на временској линији у модерном грчком језику, не само да представља предмет интересовања бројних лингвиста, већ и једну од потешкоћа са којом се могу сусрести студенти르 овог језика као J2, а који не мора као такав постојати у њиховом матерњем језику.

\section{2. О перфекту у модерном грчком језику}

Перфекат у модерном грчком језику, са морфолошке тачке гледишта, представља перифрастичко време које се репрезентује свезом презента помоћног

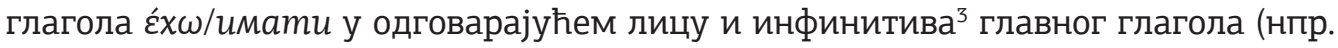

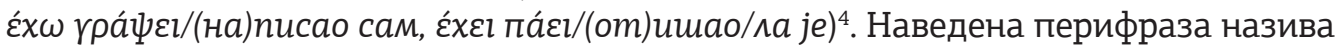

1 Треба имати на уму да иако језици који немају категорију глаголског времена као такву тренутак одвијања радње могу искзати индиректним путем (Bhat, 1999: 15).

2 Наведени термин у овом раду одговараће и термину „ученик“ који има шире значење. Термин „студент“, поред свог основног значења, дакле, означаваће и појединца који учи одређени страни језик.

3 Инфинитив (апарє́цфато), непроменљив глаголски облик, у модерном грчком језику може бити активан (бєl,

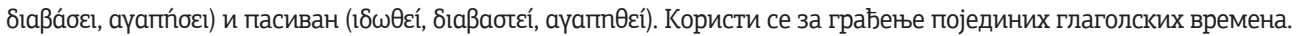

4 Наиме, перифраза є́х $\omega$ + инфинитив аориста, која чини и тежиште анализе овог рада, користи како би се на- 
се још и његовим основним обликом, односно првим или правим перфектом

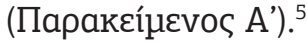

Како се у литератури наводи (Holton, Mackridge и др., 2004: 300; Рађеновић,

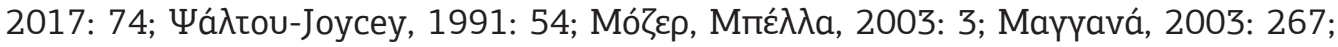
Тријандафилидис, 1996: 181), будући да се перфекат у модерном грчком језику користи како би се радња која је започета у прошлости повезала са садашњошћу, односно, истакло да је радња о којој говоримо већ остварена у тренутку говора, он се убраја, како у презентска, тако и у прошла времена 6 . Ипак, потребно је нагласити да се перфекат не може односити на радње које се одвијају у непосредној садашњости, већ на оне које су од презента одвојене одређеним времен-

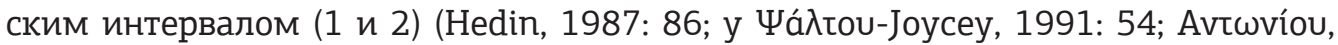
2006: 97).

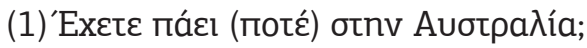
Да ли сте (икада) ишли у Аустралију?

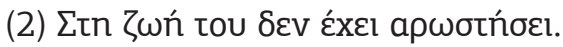
Никада се у животу није разболео.

Интересантна је чињеница да се одређена својства перфекта у модерном грчком подударају са онима карактеристичним за аорист ${ }^{7}$, те да из тог разлога, говорник може радије одабрати аорист, као доминантније време, чак и када је

гласила сама глаголска радња, те се из тог разлога у појединим случајевима иста може заменити аористом. Конкретније, перфекат ближе се дели у три групе. Поред првог перфекта, тј. перифразе са инфинитивом,

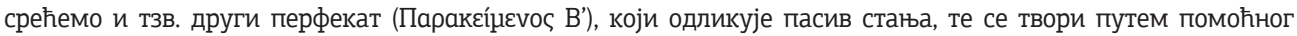

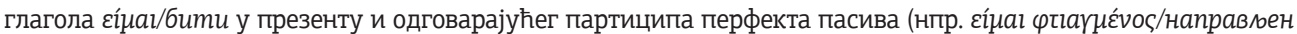

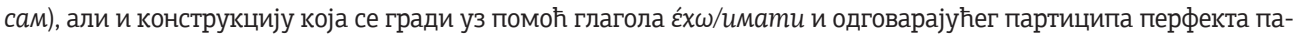

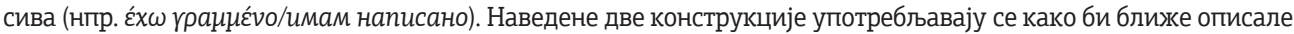
последицу глаголске радње (Мо́孔દр, 1988; Мутавџић, Тодоровић и др., 2011: 84-85; Рађеновић, 2017: 117-118).

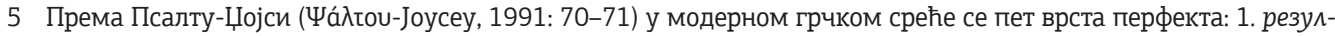
тативни (описује радњу из непосредне прошлости чији се ефекат осећа у тренутку говорења); 2. универзални (употребљава се за описивање радње која ће трајати и после тренутка саопштавања); 3. егзистенцијални (означава радњу започету у прошлости, која се вероватно понављала више пута до тренутка говорења, али ни број понављања нити трајање радње не морају бити истакнути); 4. перфекат скорије прошлости (одређује га близина вршења радње тренутку говорења, што је условљено и временским адвербијалима; осим тога, одређује га и субјективни став говорника који одлучује да ли је радња везана за садашњост или прошлост, те перфекат употребљава уз временске одредбе које означавају прошлост - нпр. јуче/хєєৎ) и 5 . универзални. С друге стране, према Комрију (Comrie, 1976: 56-61) перфекат се дели на 1. резултативни; 2. перфекат искуства; 3. перфекат перзистентне ситуације и 4. перфекат скорије прошлости.

6 То се може објаснити чињеницом да је перфекат време које се среће још у класичном грчком језику. Конкретније, радило се о монолектичком времену које се користило како би била исказана последица радње која се претходно одвијала. У хеленистичко доба перфекат подлеже пред аористом да би се, као такав,

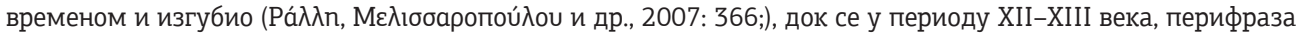
$\varepsilon \dot{x} \omega+$ инфинитив употребљавала ради означавања стандардног облика футура. Појава данашњег облика који називамо перфектом у савременом грчком језику објашњава се чињеницом да је истом било потребно време којим ће се изражавати радња која се односи на садашњост, али која је ипак старија од оне која се одвија у тренутку говора (Horrocks, 1997: 229; Moser, 2003).

7 Како примећује Рађеновић (2017: 84) уколико би се аорист у модерном грчком могао поредити са неким временом у српском језику то би био перфекат. Међутим, ово поређење смештено је у груби оквир будући да се глаголски системи морају посматрати те компарирати искључиво као целине, а не на основу својих изолованих делова, управо због својих особености, те специфичних употреба поједничаних глаголских времена. 
могуће искористити перфекат уколико то дозвољава и са̂м контекст реченице (3 и 4) (Рађеновић, 2017: 76; Мутавџић, Тодоровић и др., 2011: 84).

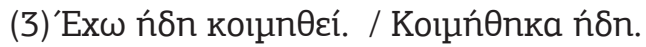
Већ сам заспао/-ла.

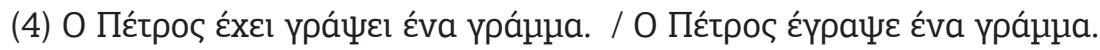
Петрос је написао једно писмо.

С тим у вези Рађеновић (2017: 132) тврди да је перфекат, у односу на аорист, потпуно неутралан када је реч о тренутној релевантности ${ }^{8}$, чиме се објашњава могућност замене перфекта аористом у свим оним значењима где радња исказана перфектом у садашњости наставља да постоји (5), док аорист тада не може бити замењен перфектом (6).

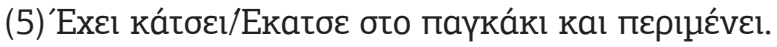

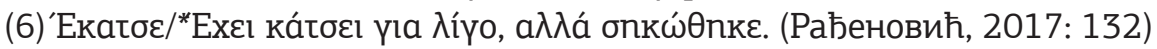

Међутим, уколико говорник настоји да посебно истакне последицу радње, уочава се да ће он у таквим ситуацијама ипак радије употребити перфекат. Конкретније, уколико се тежи стављању акцента на добијени резултат или на саму глаголску радњу, употреба перфекта, који ће тада попримити афективно семантичко значење, имаће предност (Мутавџић, Тодоровић и др., 2011: 84). Додатно, перфекат не исказује стање које произлази из неке претходне радње, што је повезано са чињеницом да он нема највећу тренутну релевантност. Ово време говорник ће користити да би означио претхођење глаголске радње, односно саму радњу у случају да има утисак да је од њеног извршења протекло

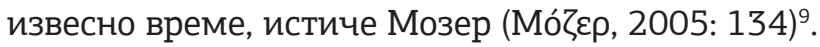

Ближе објашњење у вези са позиционирањем перфекта у различитим временским сферама, односно садашњости и прошлости, може пружити студија

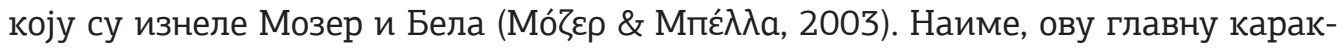
теристику перфекта ауторке повезују са његовом индикативношћу, будући да уз њега у савременом грчком језику не могу стајати адвербијали који се употребљавају за исказивање радње у прецизном тренутку у прошлости (нпр. *ХӨعৎ

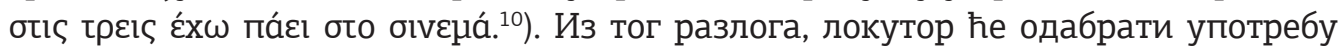
перфекта онда када жели да акценат стави на однос догађаја и простора током говорног чина (а не на питања где? зашто? како? и сл). Таква радња ће бити смештена у оквире предсадшњности (pre-present sector). С друге стране, говорнику ће бити ближа употреба аориста онда када се његово интересовање не

8 Термин тренутна релевантност (енг. current relevance) односи се на значење које носи перфекат, а којим се показује да су прошла радња или догађај на неки начин повезани са садашњим временом (Declerck, Reed и др., 2006: 301).

9 Као потпору овим тврдњама ауторка наводи и следећи пример: Уколико неко поломи руку и у том тренутку

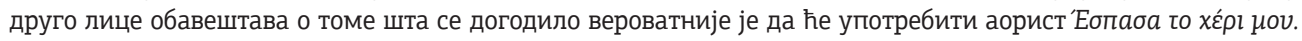

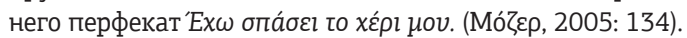

10 Будући да у српском језику ово време најчешће преводимо перфектом превод овог исказа гласио би Jуче $y$ три сата сам ишао у биоскоп. те се не може видети разлика у значењу које носи грчки перфекат и аорист, а која је на том језику јасна. 
базира на представљању радње као једног дела простора током говорног чина

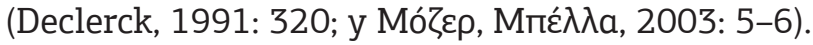

\section{1. Питање аспекта}

Поред традиционалне поделе глаголских времена, прихвата се и становиште према којем се начин на који говорник поима и представља глаголску радњу везује за аспект ${ }^{11}$, а не за време (Xydopoulos, 1996: 97). Како перфекат у модерном грчком нема јасно одређене особине, попут других глаголских времена, те због чињенице да га карактеришу особине како садашњег, тако и прошлог времена, поједини лингвисти перфекат посматрају као аспект, а не глаголско време.

Тако, према тврдњама које износи Макриџ (Mackridge, 1985: 116), будући да перфекат поседује особине карактеристичне и за садашња и за прошла времена, затим да се састоји од два глаголска облика (помоћног глагола и инфинитива), те да може показивати особине и имперфективности и перфективности, исти може бити замењен другим аспектом, и то углавном перфективним. Управо наведена особина, према аутору, перфекат чини једном засебном категоријом.

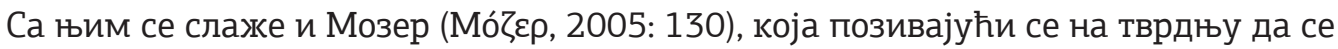
свршена времена могу сместити у различите временске сфере на темпоралној линији, истиче да се перфекат може посматрати као трећи тип аспекта.

Међутим, постоје и аутори који ово питање посматрају из другог угла. Тако, у складу са подацима истакнутим у новијој студији коју су спровели Мутавџић, Тодоровић и др. (2011: 96-98) перфекат се не може посматрати као трећи вид аспекта, већ евентуално као аспекатска варијанта (подврста тренутног аспекта). Конкретније, реч је о својеврсној тачки гледишта унутар већ постојеће тачке гледишта. То значи да перфекат има функцију унутрашњег тј. дубинског аспекта, док се аорист карактерише као спољашњи тј. генерализовани аспект. Аутори додају да управо из овог разлога одабир аориста указује на објективан став локутора према глаголској радњи, док се одабиром перфекта акценат ставља на конкретно саопштавање. Другим речима, наведени избор ће имати везе са тачком посматрања глаголске радње (као даље или као ближе), те ће локутор употребом перфекта поставити у исказу „психолошко-визуелне границе темпоралног трајања глаголске радње која је аспектом уобличена“. Дакле, локутор употребом перфекта жели да истакне своју личну заинтересованост за догађај,

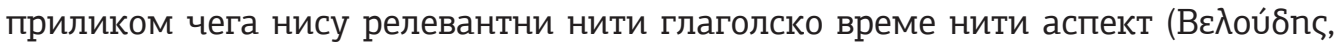
1990: 363; у Мутавџић, Тодоровић и др., 2011: 91).

\section{3. Укратко о аористу}

Како је у модерном грчком језику доминантно време за означавање радње у прошлости аорист, у наставку рада ћемо настојати да истакнемо и његове ос-

11 У савременом грчком језику сва времена су одређена перфективношћу и имперфективношћу (Рађеновић, 2017: 46). Аспект, дакле, за разлику од глаголског времена које указује да се радња локализује у односу на неки временски репер, тежиште ставља на начин представљања глаголске ситуације (у току, целини, појединим својим фазама, као навика итд) (Станојевић, 2012: 142). 
новне одлике, те утврдимо у којој мери се карактеристике и употреба овог времена и перфекта могу подударати. Аорист се у савременом грчком језику може дефинисати као време које указује да се радња коју означава глагол догодила у прошлости, али и да акценат није на њеном трајању или понављању, већ искључиво на чињеници да је извршена. Такође, битно је навести да антериорност аориста није означена у односу на тренутак говорења. Тако се радња исказана аористом може сместити, како у непосредну прошлост (7), тако и у скорију или

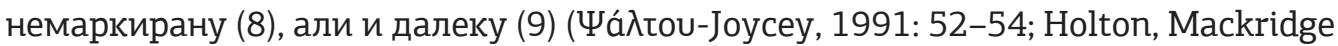
и др., 2004: 295; Тろа́ртگavos, 1946: 271; Тријандафилидис, 1996: 181; Maүүavá, 2015: 237; Рађеновић, 2017: 96).

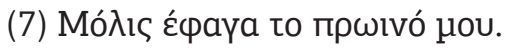

Управо сам појео/ла свој доручак.

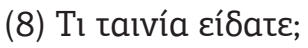

Који сте филм погледали?

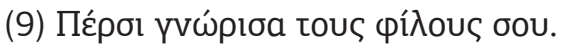

Прошле године сам упознао/ла твоје пријатеље.

Дакле, основна одлика аориста, који је и у усменом и у писаном дискурсу најчешће у употреби, јесте управо синоптички приказ радње у целости

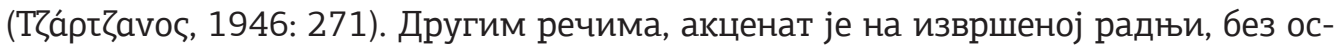
врта на њен почетак, односно трајање и крај, док се може употребљавати и уз различите временске одредбе (нпр. јуче, пре неколико дана, претходног месеиа, прошие године и сл.) $)^{12}$.

Као што смо већ навели, како је аорист време које има веома широку употребу у савременом грчком језику ${ }^{13}$, он се, поред наведених ситуација може употребити да искаже радњу која се одвијала кратко (10), затим ону радњу која се десила више пута (11), али и ону радњу која је трајала један дужи временски период (12) (Leontaridi, 2001: 243; у Рађеновић, 2017: 97).

(10)’Ебтаба то поти́рі.

Разбио/ла сам чашу.

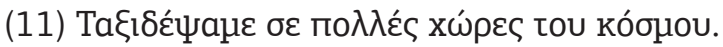

Путовали смо у многе земље света.

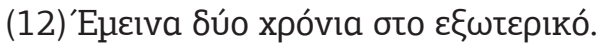

Две године сам живео/ла у иностранству.

12 Могућност аориста да буде повезан са одређеним временским адвербијалима објашњава се чињеницом да исти поседује способност да функционише анафорички, за разлику од перфекта. Другим речима, употребљава се да би се изразио временски период у којем се радња одвија, а који је већ на неки начин одређен. Конкретније, реч је о повезивању догађаја изнетог у реченици са одређеним временом у прошлости, тј. периодом који је активан и препознатљив (Michaelis, 1998: 226).

13 Поред тога што је основа одлика аориста означавање радње која се одвијала у прошлости, интересантно је да се он у модерном грчком може употребљавати са циљем означвања неког тренутка у будућности (нпр. $\Sigma \varepsilon \lambda i ́ \gamma о$

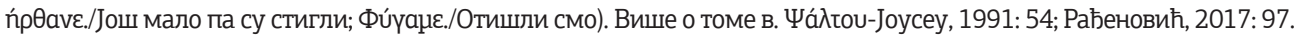




\section{4. Улога темпоралних адвербијала}

На потенцијалну замену једног од ова два времена другим, поред контекста реченце, могу утицати и временске одредбе и допуне, које у великој мери доприносе семантичкој интерпретацији реченице (Binnick, 1991: 300). Иако поједини адвербијали упућују на употребу једног конкретног глаголског времена, постоје и они који се могу употребити у више ситуација, како у зависности од аспекта, тако и значења које реченица носи. Саме адвербијале, у складу са моделом ${ }^{14}$ који предлаже Ксидопулос (Xydopoulos, 1996: 150) можемо поделити на оне који захтевају употребу перфективног аспекта ( $и$ ча фора́/jеданпут,

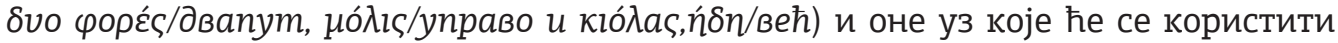

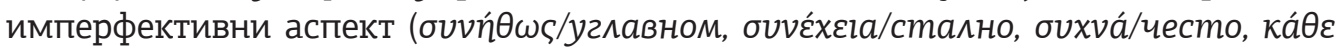
це́ра/сваког дана, каӨпнєрıvá/свакодневно, таклıка́/редовно, па́vта/увек).

Стога, будући да и перфекат и аорист не означавају радњу која је трајала или се понављала, већ да та времена акценат стављају на повезивање радње у прошлости са садашњошћу, односно на приказ радње у целости, уз њих ће се употребљавати темпорални деиктици перфективног аспекта. Међутим, као што смо већ истакли, треба имати у виду да уз перфекат у модерном грчком неће стајати адвербијали који прецизно одређују време одвијања глаголске радње.

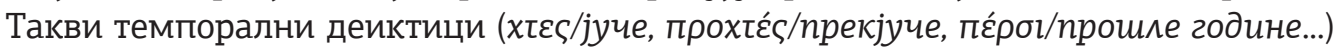
биће одлика других прошлих времена, између осталог и аориста (13). С друге стране занимљиво је приметити да, иако се перфекат не употребљава уз наведени тип деиктика ${ }^{15}$, аорист је, с друге стране, могуће употребити са темпоралним адвербијалним модификаторима за тзв. несвршену антериорност који

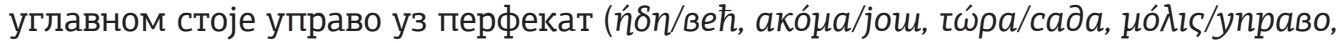

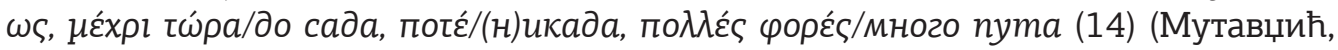
Тодоровић и др., 2011: 93).

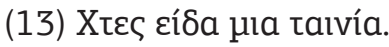

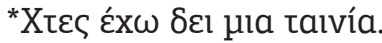

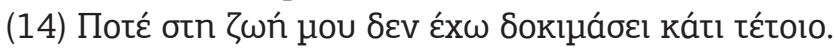

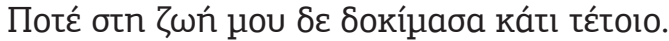

\section{5. Истраживање}

За потребе овог рада спровели смо истраживање које је имало за циљ да испита у којој мери студенти савременог грчког језика као страног употребљавају перфекат, односно да ли више теже употреби аориста или перфекта, те да ли адвербијали у реченицама њима као ненативним говорницима грчког језика

14 Адвербијали се на основу временског смештања радње могу делити на: 1. оквирне (одређују тренутак вршења одређена радња (прошле недеюе, у поноћ, 1986); 2. адвербијале броја и учесталости (означвају број или фреквентност вршења радње) и 3. дуративне (истичу трајање радње) (Binnick, 1991: 305-306).

15 Ипак, може се приметити да се понекад у свакодневном говору могу срести облици перфекта који стоје уз претходно наведене темпоралне деиктике (Чádtou-Јoусеу, 1991), што се може довести у везу са субјективним ставом локутора (о чему је претходно било речи). 
могу указати на употребу једног од ова два времена. Почетне хипотезе биле су да ће се студенти приликом попуњавања упитника ослањати на темпоралне адвербијале који се налазе у исказима, да ће у већини ситуација где је могуће употребити оба времена дати предност аористу, али и да ће уколико у одређеним исказима посебно желе да нагласе последицу радње, односно да је повежу са садашњошћу, употребљавати перфекат.

За потребе истраживања коришћен је анониман упитник ${ }^{16}$ у виду текста који се састојао од двадесет питања отвореног типа, на која је студенти требало да одговоре стављајући глаголе наведене у основном облику у перфекат или у аорист. У истраживању је учествовало укупно двадесет и двоје студената друге године основних академских студија и спроведено је у новембру 2020. године. Општи подаци испитаника приказани су у Табели бр. 1.

\begin{tabular}{|c|c|c|c|c|}
\hline \multicolumn{2}{|c|}{ Пол } & \multicolumn{3}{c|}{ Узраст } \\
\hline Мушки & Женски & $\mathbf{1 9}$ & $\mathbf{2 0}$ & $>\mathbf{2 0}$ \\
\hline $14 \%$ & $86 \%$ & $45 \%$ & $41 \%$ & $14 \%$ \\
\hline
\end{tabular}

Табела 1. Општи подаци испитаника

Исказе, односно празнине које је анкетирани студенти требало да попуне датим глаголима можемо класификовати на оне уз које стоје темпорални деиктички адвербијали који одређују презицан тренутак одвијања радње у прошлости, затим на оне уз које стоје адвербијални модификатори који означавају несвршену антериорност и, најзад, на оне уз које не стоје никакве временске одредбе.

Анализирајући одговоре које су испитаници дали, запажамо да се велики проценат испитаника управо ослањао на темпоралне адвербијале који могу указати на употребу одређених глаголских времена. С тим у вези, у свим оним захтевима где се налазе временске одредбе које одређују прецизан тренутак

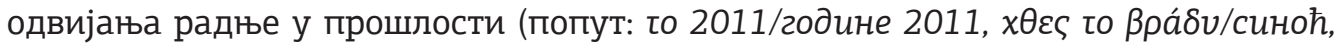

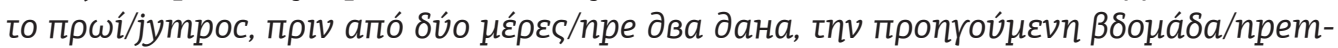

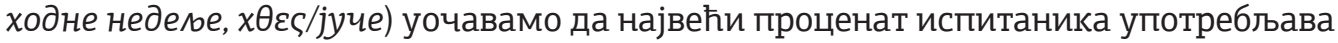
управо аорист, као што је приказано у наставку (Табела бр. 2):

16 Истичемо да упитник није стандардизован те да, самим тим, добијени резултати не могу бити генерализовани. Такође, потребно је нагласити да су у истраживању учествовали студенти који су положили курс Савремени грчки језик Г-2 (обрадивши сва глаголска времена у складу са курикулумом) $и$ стекли граматичку компетенцију на A2 нивоу у складу са 3ЕОJ-ем. Тако је наше истраживање базирано на употреби перфекта у раној фази усвајања модерног грчког језика као J2. 


\begin{tabular}{|c|c|c|c|c|}
\hline \multicolumn{2}{|c|}{ Захтеви: } & \multirow{3}{*}{ 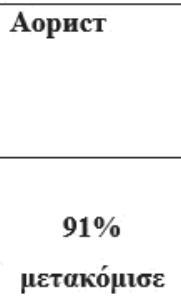 } & \multirow{3}{*}{$\begin{array}{c}\text { Перфекат } \\
0 \\
0\end{array}$} & \multirow{3}{*}{$\begin{array}{l}\begin{array}{l}\text { Није } \\
\text { дат } \\
\text { одговор }\end{array} \\
\\
9 \%\end{array}$} \\
\hline \multirow[t]{2}{*}{$\mathbf{1 .}$} & 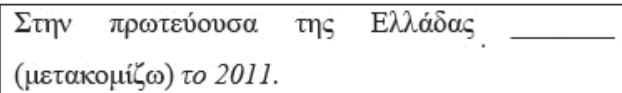 & & & \\
\hline & У престоницу Грчке се преселио 2011. године. & & & \\
\hline \multirow[t]{2}{*}{2.} & 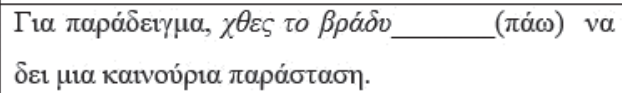 & \multirow{2}{*}{$\begin{array}{l}91 \% \\
\pi \dot{\eta} \gamma \varepsilon\end{array}$} & \multirow[t]{2}{*}{0} & \multirow[t]{2}{*}{$9 \%$} \\
\hline & $\begin{array}{l}\text { На пример, синоћ је ишао да погледа једну } \\
\text { нову представу. }\end{array}$ & & & \\
\hline \multirow[t]{2}{*}{3.} & 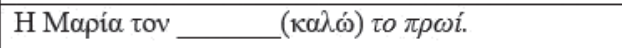 & \multirow{2}{*}{ 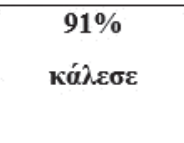 } & \multirow{2}{*}{ 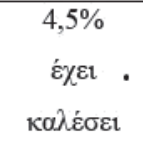 } & \multirow[t]{2}{*}{$4,5 \%$} \\
\hline & Марија га је позвала јутрос. & & & \\
\hline \multirow[t]{2}{*}{4.} & 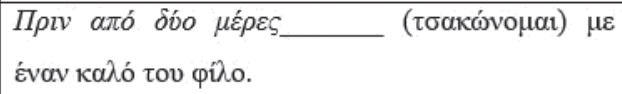 & $54 \%$ & $1 \%$ & $41 \%$ \\
\hline & $\begin{array}{l}\text { Пре дєа дана посвађао се са једним добрим } \\
\text { пријатељем. }\end{array}$ & 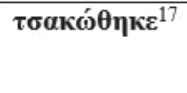 & $\begin{array}{c}\varepsilon \dot{\varepsilon} \chi \varepsilon 1 \\
\tau \sigma \alpha \kappa \omega \theta \varepsilon i\end{array}$ & \\
\hline \multirow[t]{2}{*}{5.} & 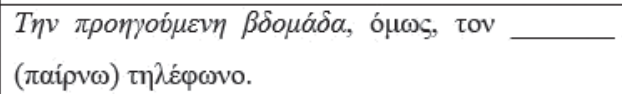 & \multirow[t]{2}{*}{$\begin{array}{l}68 \% \\
\pi \dot{\eta} \rho \alpha\end{array}$} & \multirow[t]{2}{*}{0} & \multirow[t]{2}{*}{$32 \%$} \\
\hline & Прекјуче, међутим, позвао сам га телефоном. & & & \\
\hline \multirow[t]{2}{*}{6.} & 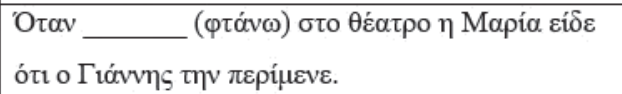 & \multirow[t]{2}{*}{$\begin{array}{l}\mathbf{5 5 \%} \\
\varepsilon \dot{\varphi} \varphi \alpha \sigma \varepsilon\end{array}$} & \multirow{2}{*}{$\begin{array}{c}36 \% \\
\varepsilon ́ \chi \varepsilon \imath \\
\varphi \tau \alpha ́ \sigma \varepsilon \imath\end{array}$} & \multirow[t]{2}{*}{$9 \%$} \\
\hline & $\begin{array}{l}\text { Када је стигла у позориште Марија је видела да } \\
\text { ју је Јанис чекао. }\end{array}$ & & & \\
\hline \multirow[b]{2}{*}{7.} & 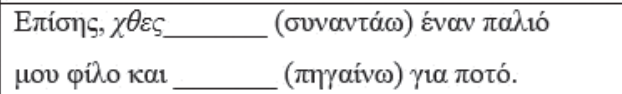 & \multirow[t]{2}{*}{ 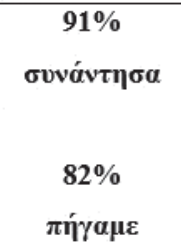 } & \multirow[t]{2}{*}{0} & \multirow[t]{2}{*}{$9 \%$} \\
\hline & $\begin{array}{l}\text { Такође, јуче сам срео једног старог пријатеља и } \\
\text { отишли смо на пиће. }\end{array}$ & & & \\
\hline
\end{tabular}

Табела 2. Искази са темпоралним адвербијалима

С друге стране, када је реч о темпоралним адвербијалним модификаторима који означавају несвршену антериорност и који стоје углавном уз перфекат, запажамо да већина студената који су учествовали у истраживању уз њих одлучује да користи управо то време (Табела бр. 3). 


\begin{tabular}{|c|c|c|c|c|}
\hline \multicolumn{2}{|c|}{ Захтеви: } & \multirow{3}{*}{ 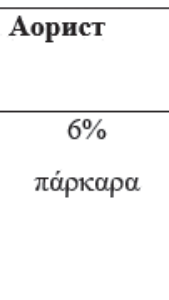 } & \multirow{3}{*}{$\begin{array}{c}\text { Перфекат } \\
59 \% \\
\varepsilon ́ \chi \omega \\
\pi \alpha \rho \kappa \alpha ́ p \varepsilon ı ~\end{array}$} & \multirow{3}{*}{$\begin{array}{r}\begin{array}{r}\text { Није дат } \\
\text { одговор }\end{array} \\
14 \%\end{array}$} \\
\hline \multirow[t]{2}{*}{1.} & 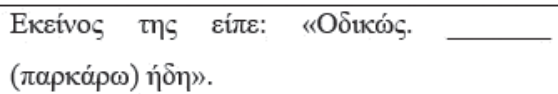 & & & \\
\hline & $\begin{array}{l}\text { Он јој је рекао: „Аутом. Паркирао сам се } \\
\text { већ“. }\end{array}$ & & & \\
\hline \multirow[t]{2}{*}{2.} & 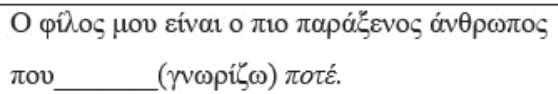 & \multirow[t]{2}{*}{$\begin{array}{l}45,5 \% \\
\gamma v \omega ́ \rho ı \alpha\end{array}$} & \multirow{2}{*}{$\begin{array}{c}\mathbf{5 0 \%} \\
\varepsilon \dot{\chi \omega} \\
\gamma \nu \omega \rho i ́ \sigma \varepsilon \mathbf{l}\end{array}$} & \multirow[t]{2}{*}{$4,5 \%$} \\
\hline & $\begin{array}{l}\text { Мој пријатељ је најчуднији човек кога сам } \\
\text { икада упознао. }\end{array}$ & & & \\
\hline \multirow[t]{2}{*}{3.} & 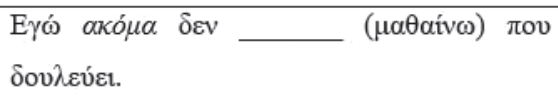 & \multirow[t]{2}{*}{ 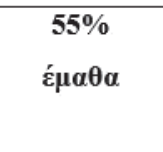 } & \multirow[t]{2}{*}{ 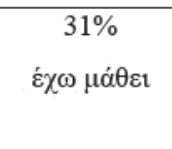 } & \multirow[t]{2}{*}{$14 \%$} \\
\hline & Ја још увек нисам сазнао где ради. & & & \\
\hline \multirow[t]{2}{*}{4.} & 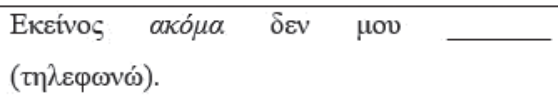 & \multirow[t]{2}{*}{$\begin{array}{c}\mathbf{5 5 \%} \\
\tau \eta \lambda \varepsilon \varphi \omega \dot{v \eta \sigma \varepsilon}\end{array}$} & \multirow{2}{*}{ 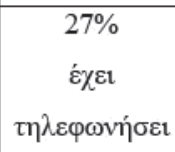 } & \multirow[t]{2}{*}{$18 \%$} \\
\hline & Он ми још увек није телефонирао. & & & \\
\hline 5. & 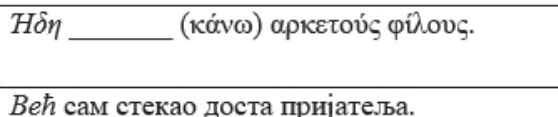 & 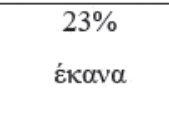 & 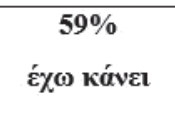 & $18 \%$ \\
\hline
\end{tabular}

Табела 3. Искази са темпоралним адвербијалним модификаторима

Интересантно је приметити да су испитаници уз темпоралне адвербијалне модификаторе наведеним у Табели бр. 3, смештали тежиште глаголске радње у перфекат, за разлику од оних уз које је стајала одредба ако́ $а$ /још увек. Иако наведене одредбе упућују првенствено на употребу перфекта (Мутавџић, Тодоровић и др., 2011: 93), будући да се уз помоћ њих прошла радња повезује са садашњошћу, већина анкетираних студената је уз исказе (3) и (4) глаголску радњу сместила у аорист. Можемо претпоставити да испитаници ову радњу посматрају као синоптичку, завршену у одређеном тренутку у прошлости без икаквих последица у тренутку говорења, те из тог разлога бирају аорист.

Најзад, последња група исказа у оквиру којих је од студената тражено да дате глаголе употребе у аористу или перфекту јесте она где није било никаквих временских адвербијала. Дакле, испитаници су морали на основу контекста, односно тока одвијања глаголске радње да исту сместе у једно од два понуђена времена. С тим у вези запажамо да већина испитаника у таквој ситуацији предност даје аористу, као што је приказано у наставку (Табела бр. 4). 


\begin{tabular}{|c|c|c|c|c|}
\hline \multicolumn{2}{|c|}{ Захтеви: } & \multirow{3}{*}{ 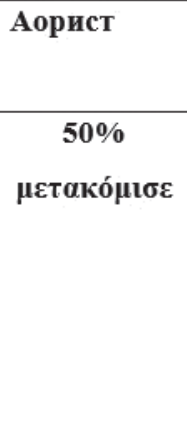 } & \multirow{3}{*}{$\begin{array}{c}\text { Перфекат } \\
27 \% \\
\dot{\varepsilon} \chi \varepsilon \iota \\
\mu \varepsilon \tau \alpha \kappa о \mu і ́ \sigma \varepsilon \iota\end{array}$} & \multirow{3}{*}{$\begin{array}{r}\text { Није дат } \\
\text { одговор }\end{array}$} \\
\hline 1. & 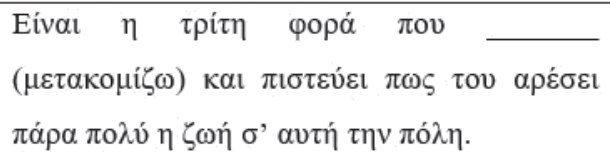 & & & \\
\hline & $\begin{array}{l}\text { Ово је трећи пут како се преселио и верује } \\
\text { да му се веома много допада живот у овом } \\
\text { граду. }\end{array}$ & & & \\
\hline \multirow[t]{2}{*}{2.} & 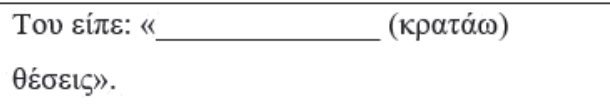 & \multirow[t]{2}{*}{ 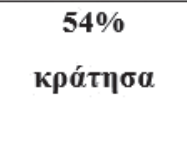 } & \multirow{2}{*}{$\begin{array}{c}23 \% \\
\dot{\varepsilon} \chi \omega \\
\kappa \rho \alpha \tau \dot{\sigma} \sigma \varepsilon \iota\end{array}$} & \multirow[t]{2}{*}{$23 \%$} \\
\hline & Рекла му је: „Резервисала сам места“. & & & \\
\hline \multirow[t]{2}{*}{3.} & 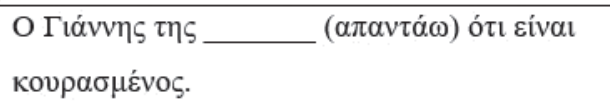 & \multirow[t]{2}{*}{$\begin{array}{c}91 \% \\
\alpha \pi \alpha ́ v \tau \eta \sigma \varepsilon\end{array}$} & \multirow{2}{*}{$\begin{array}{c}4,5 \% \\
\varepsilon \dot{\chi \varepsilon l} \\
\alpha \pi \alpha v \tau \dot{\sigma} \sigma \varepsilon l\end{array}$} & \multirow[t]{2}{*}{$4,5 \%$} \\
\hline & Јанис јој је одговорио да је уморан. & & & \\
\hline \multirow[t]{2}{*}{4.} & $\mathrm{M \varepsilon}$ & \multirow{2}{*}{$\begin{array}{c}64 \% \\
\pi \lambda \dot{\gamma} \gamma \omega \sigma \varepsilon\end{array}$} & \multirow{2}{*}{$\begin{array}{c}9 \% \\
\varepsilon \dot{\chi \varepsilon l} \\
\pi \lambda \eta \gamma \omega \dot{\sigma \varepsilon \varepsilon l}\end{array}$} & \multirow[t]{2}{*}{$27 \%$} \\
\hline & Повредило ме је његово понашање. & & & \\
\hline 5. & 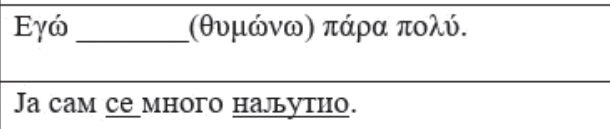 & $\begin{array}{c}72,5 \% \\
\theta v ́ \mu \omega \sigma \alpha\end{array}$ & 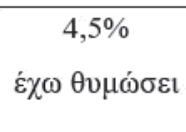 & $23 \%$ \\
\hline \multirow[t]{2}{*}{6.} & 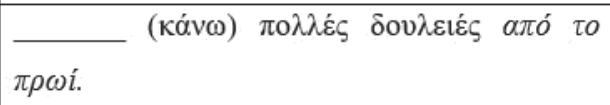 & \multirow[t]{2}{*}{$\begin{array}{l}41 \% \\
\varepsilon \dot{\kappa} \alpha v \varepsilon\end{array}$} & \multirow[t]{2}{*}{$\begin{array}{c}50 \% \\
\varepsilon x \chi \varepsilon l \text { kóvel }\end{array}$} & \multirow[t]{2}{*}{$9 \%$} \\
\hline & Урадио је много послова од јутрос. & & & \\
\hline 7. & 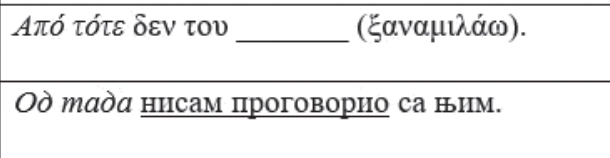 & 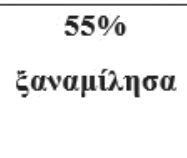 & $\begin{array}{c}36 \% \\
\varepsilon \chi \omega \\
\xi \alpha v \alpha \mu \iota \lambda \eta ́ \sigma \varepsilon \iota\end{array}$ & $9 \%$ \\
\hline
\end{tabular}

Табела 4. Искази са темпоралним адвербијалним модификаторима

Међутим, треба имати у виду да би у наведеним исказима, у већини случајева, аорист могао да буде замењен перфектом, што ће првенствено зависити од начина на који испитаници посматрају ток радње, али и од чињенице да ли радња наставља да постоји и у садашњости или не (Рађеновић, 2017: 132). Међутим, када је реч о првом исказу у датој табели, иако већина испитаника бира аорист, перфекат је тај који ће заокружити значење реченице. Такође, и употреба

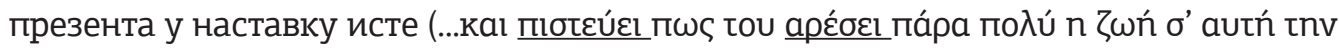


по́ $\lambda$ / ...и верује да му се веома много допада живот у овом граду) упућује на неопходност употребе перфекта који, за разлику од аориста, поседује могућност да глаголску радњу која се одвијала у прошлости повеже са садашњошћу.

Када је реч о другим исказима примећујемо да, уз изузетак исказа (6), испитаници бирају аорист, дакле стављају акценат на чињеницу да је радња започета и окончана у одређеном тренутку у прошлости. Можемо претпоставити да у том случају анкетирани студенти сматрају да наведена радња наставља да постоји и у садашњости (будући да је у исказу радња започета ујутру док је време приповедања смештено у оквире вечери истог дана) те је из тог разлога смештају у перфекат скорије прошлости, односно сматрају да шире време одвијања радње још увек није завршено.

\section{6. Дискусија и закључак}

Позивајући се на претходно изнете податке можемо потврдити почетну хипотезу да ће употреба темпоралних деиктичких адвербијала, односно модификатора, у исказима студенте модерног грчког као страног упућивати на употребу аориста, односно перфекта. С друге стране, њихово изостављање може бити проблематично будући да студенти морају дубље сагледати целокупну радњу, као и њене последице. Можемо потврдити и хипотезу која се односи на доминантнију употребу аориста (чак и онда) када је могуће употребити перфекат, али и, с тим у вези, не можемо потврдити и трећу која се односила на употребу перфекта када је реч о посебном истицању последице радње. Дакле, можемо претпоставити да испитаници сматрају да аорист могу употребити готово увек, не обраћајући увек пажњу на потенцијалну разлику у значењу до које коришћење ова два времена може довести. Позивајући се на наведене податке можемо дати даљи позитивни допринос хипотези коју износе Псалту-

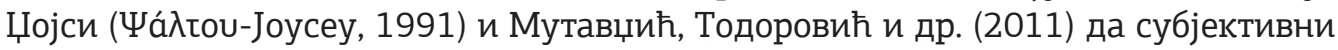
став локутора одређује начин на који посматра радњу, односно начин на који смешта предикацију у одређено време. Управо из тог разлога, можемо се сложити са ставом Мутавџића, Тодоровића и др. (2011) да се перфекат може посматрати као индивидуална тачка гледишта, те да употреба аориста у већини исказа када темпорални адвербијали не указују експлицитно на употребу перфекта, означава објективан став говорника према глаголској радњи.

Такође, сматрамо да на добијене резултате битно утиче и непостојање перфекта као таквог у српском језику, те немогућност појаве позитивног трансфера који би анкетираним студентима могао указати на који начин да сагледају радњу и да, евентуално, уместо аориста употребе перфекат када то и контекст дозвољава. Ипак морамо имати у виду да је групу испитаника чинила група студената друге године основних академских студија те да би резултати могли бити другачији уколико би се истраживање овог типа спровело међу студентима виших година студија. Дакле, ово истраживање може представљати основ за неко наредно које би проверило каква је ситуација када је реч о Б2 и Ц1 нивоу у складу са ЗЕОЈ-ем.

Питање улоге и позиционирања перфекта представља једну комплексну област у савременом грчком језику будући да и сами лингвисти имају опречна 
мишљења о истом. Свакако, значајно је и утврдити на који начин ненативни говорници овог језика гледају на перфекат. Према резултатима спроведеног истраживања студенти модерног грчког му у односу на аорист додељују секундарну улогу.

Мишљења смо да је на ову тему потребно спровести још истраживања, како квалитативног, тако и квантативног типа, те укључити већи број испитаника са других универзитета и/или ненативне говорнике других језика како би се добила свеобухватнија слика у вези са начином на који перфекат посматрају ненативни говорници овог језика. Такође, било би значајно спровести сличну анкету у којој би учествовали нативни говорници модерног грчког језика, те утврдити у којим ситуацијама би они предност дали перфекту, односно, аористу. Најзад, сматрамо да би резултати таквих истраживања допринели оптимизацији наставе граматике модерног грчког, а самим тим и повећању комуникативне компетенције студената овог језика као J2.

\section{Литература}

Мутавџић, П., Тодоровић, Д., Рађеновић, А. (2011). О перфекту у савременом грчком и о неким његовим сличностима са перфектом у српском језику. Филолошки преглед, 38(1), 83-103.

[Mutavdžić, P., Todorović, D., Rađenović, A. (2011). O perfektu u savremenom grčkom i o nekim njegovim sličnostima sa perfektom u srpskom jeziku. Filološki pregled, 38(1), 83-103]

Рађеновић, А. (2017). Индикатив претерита у грчком и српском језику (необјављена докторска дисертација). Филолошки факултет Универзитета у Београду.

[Rađenović, A. (2017). Indikativ preterita u grčkom i srpskom jeziku (neobjavljena doktorska disertacija). Filološki fakultet Univerziteta u Beogradu]

Станојевић, В. (2012). Перфективност и теличност у српском са освртом на ситуацију у француском језику. Научни састанак слависта у Вукове дане, 41(1), 141-155.

[Stanojević, V. (2012). Perfektivnost i teličnost u srpskom sa osvrtom na situaciju u francuskom jeziku. Naučni sastanak slavista u Vukove dane, 41(1), 141-155]

Станојчић, ЖК., Поповић, љ. (1997). Граматика српског језика. Београд: Завод за уџбенике и наставна средства.

[Stanojčić, Ž., Popović, Lj. (1997). Gramatika srpskog jezika. Beograd: Zavod za udžbenike i nastavna sredstva]

Тријандафилидис, М. (1995). Мала новогрчка граматика. Тесалоника: Аристотелов универзитет у Тесалоники, Институт за новогрчке студије, Фондација Манолиса Тријандафилидиса.

[Trijandafilidis, M. (1995). Mala novogrčka gramatika. Tesalonika: Aristotelov univerzitet u Tesaloniki, Institut za novogrčke studije, Fondacija Manolisa Trijandafilidisa]

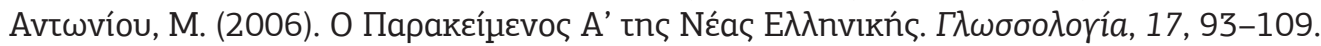
[Antoniou, M. (2006). O Parakeimenos A' tis Neas Elliniks. Glossologia, 17, 93-109] Bhat, S. (1999). The Prominence of Tense, Aspect and Mood. Amsterdam: John Benjamins Publishing. 
Binnick, R. (1991). Time and the Verb: a Guide to Tense \& Aspect. New York: Oxford University Press.

Binnick, R. (2012). The Oxford Handbook of Tense and Aspect. New York: Oxford University Press.

Comrie, B. (1985). Tense. Cambridge: Cambridge University Press.

Declerck, R., Reed, S., Cappelle, B. (2006). The Grammar of the English Tense System: A Comprehensive Analysis. Berlin/New York: Mouton de Gruyter.

Holton, D., Mackridge, P., Philippaki-Warburton, I. (2004). Greek: a comprehensive grammar of the modern language. London/New York: Routledge.

Horrocks, G. (1997). Greek: A History of the Language and its Speakers. London/New York: Longman Linguistics Library.

Joshi, M. (2014). Using Tenses in English: Past, Present, Future. Manik Joshi.

Lakoff, G., Johnson, M. (1980). Metaphors we Live by. Chicago: University of Chicago Press. Lyons, J. (1977). Semantics. Cambridge: Cambridge University Press.

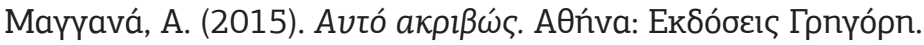

[Mangana, A. (2015). Afto akrivos. Athens: Grigori Publications]

Mackridge, P. (1985). The Modern Greek Language: a Descriptive Analysis of Spoken Modern Greek. New York: Oxford University Press.

Michaelis, L. (1998). Aspectual grammar and past-time reference. London/New York: Routledge: Routledge.

Michaelis, L. (2006). Time and Tense. In B. Aarts and A. McMahon (Eds.), The Handbook of English Linguistics (pp. 220-243). Oxford: Blackwell.

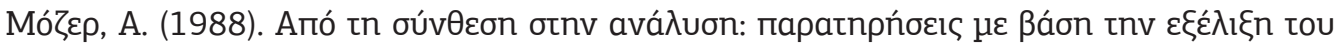

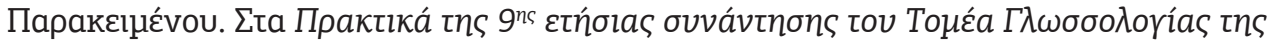

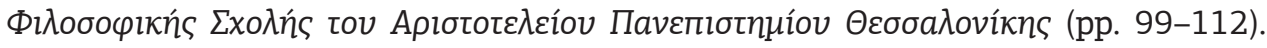

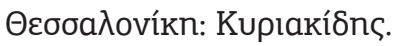

[Mozer, A. (1988). Apo ti synthesi stin analysi: paratiriseis me vasi tin ekseliksi tou Parakeimenou. In Proceedings of $9^{\text {th }}$ Annual Meeting of the Department of Linguistics, Faculty of Philosophy, Aristotle University of Thessaloniki (pp. 99-112). Thessaloniki: Kyriakidis]

Moser, A. (2003). Perfect Explorations. New York: Mouton de Gruyter.

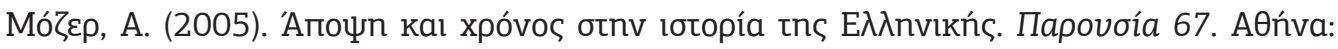

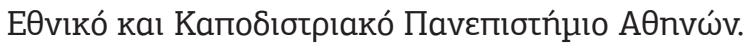

[Mozer, A. (2005). Apopsi kai chronos stin istoria tis Ellinikis. Parousia 67. Athens: National and Kapodistrian University of Athens]

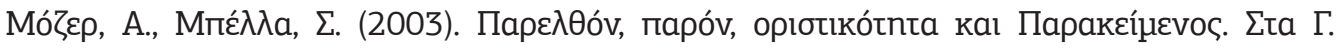

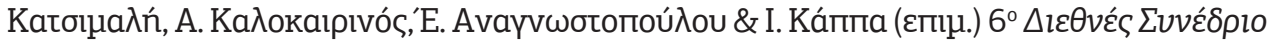

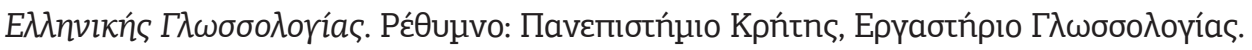

[Mozer, A., Mpella, S. (2003). Parelthon, paron, oristikotita kai Parakeimenos. In G. Katsimali, A. Kalokairinos, E. Anagnostopoulou \& I. Kappa (Eds.), $6^{\text {th }}$ International Conference on Greek Linguistics. Rethymno: University of Crete, Linguistics Workshop]

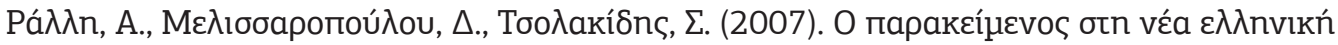

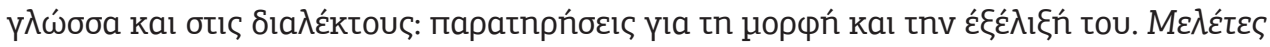

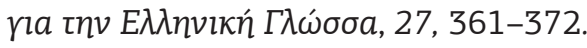


[Ralli, A., Melissaropoulou, D., Tsolakidis, S. (2007). O parakeimenos sti nea elliniki glossa kai stis dialektous: paratiriseis gia ti morf kai tin ekseliksi tou. Meletes gia tin Elliniki Glossa, 27, 361-372]

Thalberg, I. (1963). Tenses and 'Now'. The Philosophical Quarterly (1950-), 13(53), 298310.

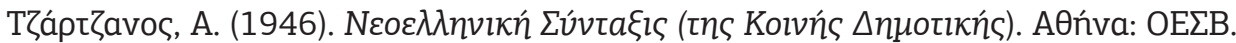

[Tzartzanos, A. (1946). Neoelliniki Syntaksis (tis Koinis Dimotikis). Athens: OESV]

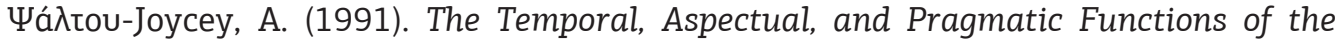
Perfect in Modern Greek (unpublished doctoral dissertation). Aristotle University, Thessaloniki.

[Psaltou-Joycey, A. (1991). The Temporal, Aspectual, and Pragmatic Functions of the Perfect in Modern Greek (unpublished doctoral dissertation). Aristotle University, Thessaloniki]

Whorf, B. (1956). Language, Thought, and Reality - Selected Writings of Benjamin Lee Whorf (J. B. Carroll, Ed.). Cambridge, MA: MIT. Press.

Xydopoulos, G. (1996). Tense, Aspect and Adverbials in Modern Greek (unpublished doctoral dissertation). University College London.

\section{Maja G. Baćić}

\section{Summary}

\section{THIS IS THE THIRD TIME HE'S MOVED. - PERFECT OR AORIST IN MODERN GREEK?}

The paper aims to present the similarities and differences between the perfect and aorist in Modern Greek, since the positioning of the perfect on the timeline may depend on different syntactic-semantic conditions. More specifically, the perfect can be used to connect the action which started in the past with the present, and for that reason it is included in both present and past tenses. On the other hand, the aorist is the dominant past tense, and can often replace the perfect. For this reason, the perfect remains a complex topic in teaching Modern Greek as a foreign language. For the purposes of this paper, a quantitative research study was conducted with second-year undergraduate students of Modern Greek as L2 at a Department of Modern Greek Studies participated. The results of the study show that the majority of respondents chose the aorist as the more dominant tense, but if sentences did not include temporal provisions that indicated perfectivity.

\section{Key words:}

perfect, aorist, Modern Greek as L2 


\section{Appendix}

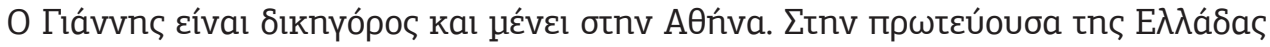

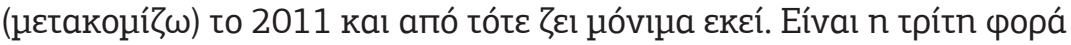
поบ

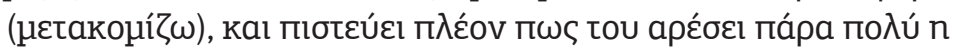

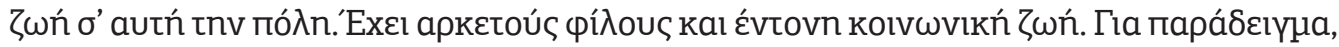
$\mathrm{x} \theta \varepsilon \varsigma$ to $\beta p a ́ \delta \mathrm{u}$

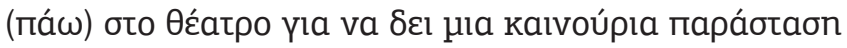

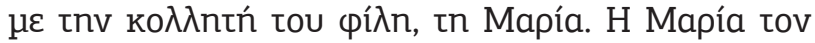

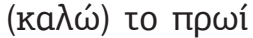
kal tou cínع: «

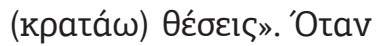
(

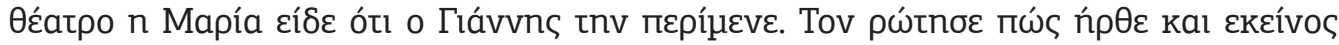

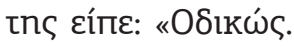

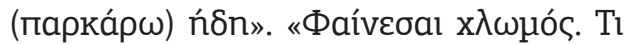

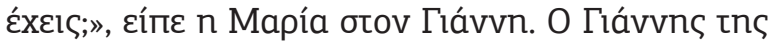
(anavtá $\omega$ ) ótıeíval

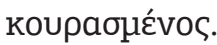
(káv

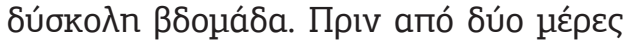
tou pí̉o kal anó tóte $\delta \varepsilon v$ tou

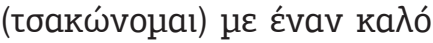

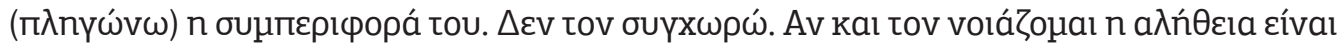

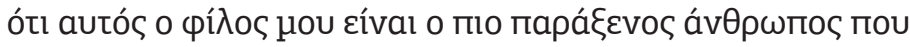
$(\gamma v \omega p i ́ \zeta \omega)$

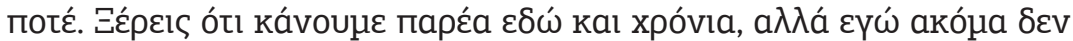

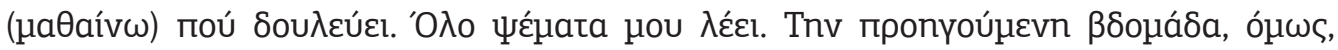
tov

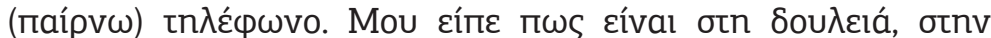

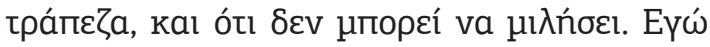

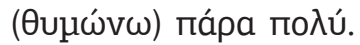

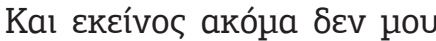

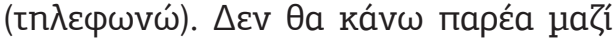
tou mla.'Hon

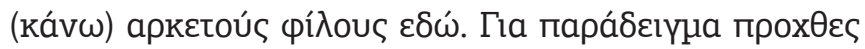

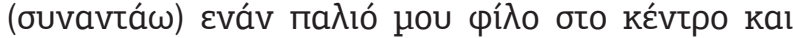

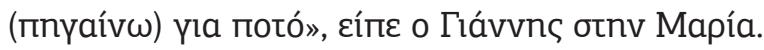

